\title{
Syphilis and HIV infection in patients with hepatitis A: a preliminary study from one centre in Poland
}

\author{
Maciej Bura1 ${ }^{1}$ Aleksandra Bura², Iwona Mozer-Lisewska ${ }^{1}$ \\ ${ }^{1}$ Department of Infectious Diseases, Hepatology and Acquired Immunodeficiencies; Poznan University of Medical Sciences, \\ Poznan, Poland \\ ${ }^{2}$ Department of Infectious Diseases, Jozef Strus Multidisciplinary City Hospital, Poznan, Poland
}

Adv Dermatol Allergol 2020; XXXVII (5): 810-811 DOI: https://doi.org/10.5114/ada.2020.100493

In 2017, there was a significant increase in hepatitis A incidence in Poland and several dozen times more cases were reported in comparison to previous years [1]. For instance, in the reference centre for infectious diseases for the Greater Poland Voivodeship in the period from the beginning of February to the end of August 2017, more patients with hepatitis A were hospitalized than in the previous 10 years in total.

As hepatitis A virus (HAV) infections are transmitted through the faecal-oral route, hepatitis A can spread during intimate contacts and some specific sexual practices $[2,3]$. For this reason, we hypothesized that it could be an indicator of risky sexual behaviours and diagnosis of hepatitis A may be an opportunity to test patients for other sexually transmitted infections (STI).

Persons hospitalized at the Department of Infectious Diseases in Poznan (Jozef Strus Multidisciplinary City Hospital) for symptomatic HAV infection from February to mid-August 2017 were included in the present analysis.

The objectives of this study were a simple demographic description of patients with hepatitis A and their screening for some STI that may be asymptomatic (syphilis, HIV infection, hepatitis B, hepatitis C).

The study was approved by the local Bioethics Committee. All patients gave their informed consent.

One hundred patients aged 20-64 (median: 29.5 years) with symptomatic hepatitis A have been screened for the above mentioned STI.

Testing for HAV (HAVAb-IgM), HBV (HBsAg Qualitative), HCV (anti-HCV) and HIV (HIV Ag/Ab Combo) infections was performed using the ARCHITECT system (Abbott Laboratories). Each positive result of the screening test for HIV infection was confirmed with the western blot technique.
RPR Carbon (Hydrex Diagnostics Sp. z o.o., Warszawa, Poland) and Immuntrep TPHA (Omega Diagnostics Ltd, Alva, Scotland) assays were used for screening and confirmation of syphilis, respectively. Syphilis was diagnosed in the following circumstances: the presence of symptoms or signs consistent with an early stage of disease (primary or secondary syphilis) and reactive RPR and TPHA tests, or a 4-fold increase from baseline in RPR titres with a reactive TPHA in patients who had syphilis in the past, or positive RPR (at least $1: 8$ titre in quantitative assessment) and TPHA in patients who have never been tested for syphilis before.

The majority of patients were men (93\%). A significant proportion of male study participants (76.3\%; 71/93) described themselves as men having sex with men (MSM).

Twenty patients (20\%; 19 men including 17 MSM) travelled abroad in the period of 2 months preceding the first symptoms of hepatitis A. All but one visited only European countries.

The peak values of hepatic biochemistry in patients from our centre are shown in the Table 1.

All but 1 patient (woman) were tested for HIV infection, and it was only found in men. In most cases (79.3\%; 23 out of 29 HIV-positive men with hepatitis A), it was diagnosed and treated with antiretroviral therapy before hospitalization for symptomatic HAV infection. The new HIV infection diagnosis concerned 6/70 men (8.6\%) who were previously HIV-negative or unaware of their HIV status.

RPR was reactive or equivocal in 20 patients out of 89 tested ( 8 men and 3 women were not examined for syphilis). All of them were MSM. When taking into account all available data (past medical history, clinical presentation along with previous and current syphilis test results), an ongoing Treponema pallidum infection was

Address for correspondence: Maciej Bura MD, PhD, Department of Infectious Diseases, Hepatology and Acquired Immunodeficiencies, Poznan University of Medical Sciences, 3 Szwajcarska St, 61-285 Poznan, Poland, phone: +48 6187393 76, fax: +48 61 877 3687 , e-mail: mbura@umed.poznan.pl

Received: 24.01.2019, accepted: 10.05.2019. 
ultimately diagnosed in 11 out of 85 men tested (12.9\%). Only 2 of them (both HIV-negative) had the symptomatic disease (secondary syphilis), 4 men (two were HIVpositive) had the first-time diagnosis of latent syphilis, and 5 patients (all were HIV-positive) had recurrent latent syphilis. In addition, 14 individuals (including $11 \mathrm{HIV}$ positive) with no active disease were treated for syphilis in the past.

The presence of HBsAg was found in 3 out of 100 subjects (all were MSM, two co-infected with HIV). They all knew about their HBV infection before the episode of hepatitis A occurred. Anti-HCV positivity was shown in 3 out of 99 persons tested. All were HIV-infected MSM, and 2 of them were aware of their HCV infection. HCV-RNA was negative in the third patient.

Based on these data from our centre, we believe that the epidemic of hepatitis A in Poland in 2017 was related to similar events in Western Europe in the earlier period [4-6].

This is supported by a high percentage of MSM among hospitalized patients with hepatitis A and a significant rate of recent travel activities among them $(23.9 \%, 17 / 71)$.

Importantly, in $17.2 \%$ (16/93) of these men, a previously unrecognized episode of STI was diagnosed.

The need for periodic screening for syphilis in HIV-positive patients and those with syphilis for HIV-infection is well documented and recommended [7]. Such a paradigm was also recently confirmed by two groups from Poland [8, 9]. Based on the results of our study, we postulate that at least in men, hepatitis A should also be an indication for a routine screening for other STI. Some previous observations suggested the validity of such an approach in Poland, and the epidemic of 2017 confirmed this [3, 10]. It is very important for STI, which may be asymptomatic, including syphilis and HIV infection. Their recognition allows to start treatment and prevent their further spreading. It should be stressed that in the current analysis, only two men with syphilis diagnosed during hospitalization for hepatitis A had symptomatic STI.

This study has some limitations. Firstly, only hospitalized patients were included in the analysis. However, in the study period, about $70 \%$ of all hepatitis A cases diagnosed in our centre concerned these inpatients. Secondly, no tests for syphilis were performed in some persons, which might result in an underestimation of this disease. Only in single cases were both HIV and HCV assays not carried out. Thirdly, while writing this Letter, no molecular testing results were available to prove linkage with outbreaks in other European countries.

In conclusion, the hepatitis A outbreak in the Greater Poland region in 2017 concerned mainly MSM. Men with hepatitis A should always be screened for other STI, including syphilis and HIV infection.

\section{Conflict of interest}

The authors declare no conflict of interest.
Table 1. Peak levels of hepatic biochemistry parameters in study participants $(n=100)$

\begin{tabular}{|c|c|}
\hline Parameter & Median (Q1-Q3) \\
\hline $\begin{array}{l}\text { Alanine aminotransferase (ALAT) [U/l] } \\
\text { Reference range: } 4-45\end{array}$ & 2847 (1423-4141) \\
\hline $\begin{array}{l}\text { Aspartate aminotransferase (AspAT) [U/I] } \\
\text { Reference range: 4-35 }\end{array}$ & $1427(475-3020)$ \\
\hline $\begin{array}{l}\text { Total bilirubin }[\mu \mathrm{mol} / \mathrm{l}] \\
\text { Reference range: } 3-17\end{array}$ & 167 (114-200) \\
\hline $\begin{array}{l}\gamma \text {-Glutamyltransferase (GGT) }[\mathrm{U} / \mathrm{l}] \\
\text { Reference range: } 5-55\end{array}$ & $248(160.5-344)$ \\
\hline $\begin{array}{l}\text { Alkaline phosphatase (ALP) [U/I] } \\
\text { Reference range: 46-116 }\end{array}$ & 209 (165-265) \\
\hline
\end{tabular}

\section{References}

1. Narodowy Instytut Zdrowia Publicznego, Państwowy Zakład Higieny - Zakład Epidemiologii Chorób Zakaźnych i Nadzoru; Główny Inspektorat Sanitarny - Departament Zapobiegania oraz Zwalczania Zakażeń i Chorób Zakaźnych u Ludzi. Choroby zakaźne i zatrucia w Polsce w 2017 roku. Available from: http:// wwwold.pzh.gov.pl/oldpage/epimeld/2017/Ch_2017_wstepne_ dane.pdf (accessed 18.01.2019)

2. Bouvet E. Sexual practices and transmission of HAV and HCV. Euro Surveill 2005; 10: 74.

3. Dabrowska MM, Nazzal K, Wiercinska-Drapalo A. Hepatitis $A$ and hepatitis A virus/HIV coinfection in men who have sex with men, Warsaw, Poland, September 2008 to September 2009. Euro Surveill 2011; 16: pii: 19950.

4. Beebeejaun K, Degala S, Balogun K, et al. Outbreak of hepatitis A associated with men who have sex with men (MSM), England, July 2016 to January 2017. Euro Surveill 2017; 22: pii $=30454$.

5. Freidl GS, Sonder GJ, Bovée LP, et al. Hepatitis A outbreak among men who have sex with men (MSM) predominantly linked with the EuroPride, the Netherlands, July 2016 to February 2017. Euro Surveill 2017; 22: pii=30468.

6. Werber D, Michaelis K, Hausner M, et al. Ongoing outbreaks of hepatitis A among men who have sex with men (MSM), Berlin, November 2016 to January 2017 - linked to other German cities and European countries. Euro Surveill 2017; 22: pii=30457.

7. Workowski KA, Bolan GA; Centers for Disease Control and Prevention. Sexually transmitted diseases treatment guidelines 2015. MMWR Recomm Rep 2015; 5: 1-137.

8. Biało-Wójcicka E, Młynarczyk-Bonikowska B, Winiarska A, et al. Syphilis in patients of the Department of Dermatology and Venereology at Medical University of Warsaw in 2015 epidemiological and clinical characteristics, and coexistence of other sexually transmitted diseases. Dermatol Rev 2017; 104: 597-605.

9. Pastuszczak M, Bociąga-Jasik M, Sitko M, Wojas-Pelc A. HIV infection and sex in sex-on-premises venues are associated with a higher risk of syphilis reinfection among men who have sex with men. Adv Dermatol Allergol 2018; 35: 481-4.

10. Bura M, Michalak M, Chojnicki MK, et al. Viral hepatitis A in 108 adult patients during an eight-year observation at a single center in Poland. Adv Clin Exp Med 2015; 24: 829-36. 